\title{
Response of Post Harvest Treatments on Shelf Life of Custard Apple (Annona squamosa L.) variety Arka Sahan during Storage
}

\author{
Megha Patidar, Jyoti Kanwar*, O. P. Singh and G. P. S. Rathore \\ Department of Horticulture, College of Horticulture, Mandsaur, India \\ Rajamata Vijaya Raje Scindia Krishi Vishwa Vidyalaya, Gwalior, M.P., India \\ *Corresponding author
}

Keywords

Custard apple

(Annona squamosa

L.), Chitosan,

Benzyl adenine,

Calcium chloride

Article Info

Accepted:

12 March 2021

Available Online:

10 April 2021

\section{A B S T R A C T}

A laboratory experiment was conducted on "Study on the effect of post harvest treatments on shelf life of custard apple (Annona squamosa L.) variety Arka Sahan during storage', at department of fruit science, college of horticulture, Mandsaur. Experiment was statistically designed in Complete Randomized Design (CRD) with three replications. There were three components with 13 treatment combinations i.e. Calcium chloride at $2 \%, 4 \%, 6 \%$, Benzyl adenine at 50ppm, 100ppm, 150ppm, Chitosan at $0.5 \%, 1.0 \%, 1.5 \%$ and their combinations and control. Physical parameter (Fruit length, Diameter and Specific gravity), Marketable and Spoilage of fruit, Biochemical parameters i.e. Total Soluble Solids, Titrable acidity and Ascorbic acid were observed. The result concluded that the higher combination of treatments (chitosan $1.5 \%+\mathrm{BA} 150 \mathrm{ppm}+\mathrm{CaCl}_{2} 6.0 \%$ ) was found to be the best for enhanced the shelf life of fruit upto 12 days with good quality and appearance of fruits as compared to control.

\section{Introduction}

Custard apple (Annona squamosa L.) is one of the finest fruits introduced in India from Tropical America. The undomesticated form of this fruit can be found in many part of India. It is also known as various names like Sugar Apple, sitaphal, sweet sop and sharifa. Fruit ripening nature of custard apple is climacteric i.e. sharp rise in respiration after harvest. Custard apple is very high perishable fruit crop with very short life of storage (Wills et al., 2001). The edible portion or pulp is a creamy and granular with a good blend of sweetness. It contains protein $(1.6 \mathrm{~g})$, fat $(0.5-$ $0.6 \mathrm{~g})$, carbohydrate (23.5 g), crude fiber (0.9$6.6 \mathrm{~g}$ ), calcium (17.6 g), phosphorus (47 $\mathrm{mg}$ ), iron $(1.5 \mathrm{~g})$, thiamine $(0.075-0.119 \mathrm{mg})$, 
riboflavin (0.086- $0.175 \mathrm{mg}$ ), ascorbic acid (15.0-44.4 mg) and nicotinic acid (0.5 mg) per $100 \mathrm{~g}$ of edible portion (Mahadevbhai and Patel, 2018). Cold storage is not promising. Moreover if fruit is allowed to remain on the tree for prolonged period, the pericarp splits to open facilitating deterioration. Because of custard apple is highly perishable, the fruits could not be send to distant markets. Commercialization of custard apple (Annona squamosa, L) is the biggest hinder for the custard apple growers due to its highly perishable nature. On an average, the postharvest shelf life of this fruit is only three to four days at ambient temperature. Therefore, it can commercialize only in the domestic market. An immediate consequence is a raise of the product's price. Hence, it is mandatory to develop a technology which allows to increase the custard apple post harvest shelf life, available to consumers with good quality and reasonable prize. It is also necessary to develop a technology which enables to extend the sugar apple postharvest shelf life, reaching the consumer with good sensory qualities and available at compensatory prices. Among the different methods, fruit coatings are one such alternative as they do not only improve external appearance, but also modify the internal atmosphere of fruits (Trung et al., 2011).

Use of semi-permeable coatings has gained importance in reducing the moisture loss, transpiration, respiration and microbial attack with maintaining firmness at ambient condition (Patel et al., 2011). Coatings make good oxygen and lipid barrier at low to intermediate RH because the polymers can effectively make hydrogen bonds (Sihag et al., 2005). For instance use of benzyl adenine (antioxidant) acts as antisenescent, stop the metabolic break down deterioration caused by various biochemical activities in the fruits (Bhardwaj et al., 2005). Calcium chloride has found promising new technology in maintaining fruit quality during storage, which alternative to disinfestations of fruit and could modify its response to other stresses. Chitosan dissolved in diluted organic acids can be used as a casting fluid to form a preservative membranous coating on the fruits that have been successfully used to maintain the quality and shows antifungal activity against several fungi (Trung et al., 2011; Li and $\mathrm{Yu}, 2001$ ). An immediate consequence is a raise of the product's price. Hence, it is necessary to develop a technology which enables to extend the sugar apple postharvest shelf life, reaching the consumer with good sensory qualities and available at compensatory prices by the application of edible coatings.

\section{Materials and Methods}

Custard apple fruits were obtained from a KVK of Chittaurgarh, Rajasthan. The full matured fruits were subjected to uniform manual grading and used for experiment in the laboratory of department of fruit science in plastic crates. The fruits were cleaned with running tap water to remove the adherent dirt material and then spread in room. The fruits were disinfected with $0.1 \%(\mathrm{w} / \mathrm{v})$ bavistin solution for 2 minutes then fruits were dipped in the coating solutions of 13 treatment combinations i.e. Calcium chloride at $2 \%, 4 \%$, $6 \%$, Benzyl adenine at 50ppm, 100ppm, $150 \mathrm{ppm}$, Chitosan at $0.5 \%, 1.0 \%, 1.5 \%$ and their combinations and control.

The chitosan solution $(1 \%, \mathrm{wt} / \mathrm{vol})$ was prepared by dissolving $1 \%$ acetic acid to accelerate the dissolution process. The $\mathrm{pH}$ of the chitosan solution was adjusted to 5.6 using I $\mathrm{N} \mathrm{NaOH}$. After applications of treatments fruits were kept in the room temperature in plastic trays. Determination of fruit length and diameter determined by using vernier caliper. The TSS content of fruit was determined by using a digital refractometer, Acidity and 
Ascorbic acid were determined by the method of Ranganna (1996).

\section{Results and Discussion}

\section{Physical Parameters}

The observations were presented as initial value (before treatment), 0 day, $4^{\text {th }}$ day, $8^{\text {th }}$ day and $12^{\text {th }}$ day. Reduction of fruit length showed an increasing trend with the increasing period of storage. The significantly minimum reduction in fruit length $(0.00 \mathrm{~cm}, 0.14 \mathrm{~cm}$, $0.22 \mathrm{~cm}$ and $0.42 \mathrm{~cm}$ ) was observed with application of treatment $\mathrm{T}_{12}\left(\mathrm{CaCl}_{2} 6.0 \%+\right.$ BA $150 \mathrm{ppm}+$ Chitosan $1.5 \%$ ) and it was significantly at par with $T_{11}(0.15 \mathrm{~cm}, 0.24 \mathrm{~cm}$ and $0.43 \mathrm{~cm}$ ) on the $4,8,12$ days of storage period, respectively. While, the maximum loss in fruit length found with $\mathrm{T}_{0}(0.00 \mathrm{~cm}, 0.25$ $\mathrm{cm}, 0.35 \mathrm{~cm}$ and $0.55 \mathrm{~cm}$ ) at $0,4,8$ and 12 days of storage period, respectively. The loss in size of fruit diameter increase significantly in respect of different postharvest treatments up to 12 days. $\mathrm{T}_{12}\left(\mathrm{CaCl}_{2} 6.0 \%+\mathrm{BA} 150\right.$ ppm + Chitosan $1.5 \%$ ) exhibited significantly minimum loss in fruit diameter $(0.00 \mathrm{~cm}, 0.15$ $\mathrm{cm}, 0.26 \mathrm{~cm}$ and $0.45 \mathrm{~cm})$ on $0,4,8$ and 12 days of storage period. Treatment $\left(T_{11}\right)$ statistically at par with the treatment $\mathrm{T}_{12}(0.16$ $\mathrm{cm}, 0.27 \mathrm{~cm}$ and $0.46 \mathrm{~cm}$ ) at 4, 8, 12 days of storage period, respectively. While, the maximum loss of fruit diameter among all the treatments was found with the control $\mathrm{T}_{0}(0.00$ $\mathrm{cm}, 0.26 \mathrm{~cm}, 0.37 \mathrm{~cm}$ and $0.58 \mathrm{~cm}$ ) on the 0 , 4, 8, 12 days of storage life respectively. Postharvest treatments of Chitosan, Benzyl adenine and $\mathrm{CaCl}_{2}$ did not significant on specific gravity over control. Although, it was showed in decreasing trend under all the post harvest treatments (Table-1).

This may be due to the combined effect of chitosan, benzyl adenine and calcium chloride. Chitosan provided better way to reduce the evaporation and avoided shrinkage resulting minimum reduction in fruit length and diameter (Medlicott et al., 1987). The maintenance of flesh firmness of chitosan coated fruits might be due to the antifungal activity of chitosan and formation of semi permeable barrier around the fruit surface, thereby reducing infection, gas exchange and other ripening processes during storage (Shiekh, et al., 2013). BA has a free radical and to extinguish property which hinder ethylene biosynthesis, caused retardation of senescence and also reduced the shrinkage of fruits during storage period in mango (Thokchom and Mandal., 2019). Similar result obtained in mandarin cv. Nagpur Santra (Bhardwaj et al., 2005). Calcium chloride at higher concentrations served as a semipermeable membrane around the fruit-surface resulting in reduction in evapo-transpiration and in the rate of respiration (Lal et al., 2011). The lower microbial growth and weight loss when the combined effect of calcium chloride with chitosan was applied over the mangoes (Chouhan, et al., 2014). Similar findings also reported by (Abdel et al., 2017) on shelf life of peach fruit.

\section{Marketable and spoilage parameters}

The effect of various treatments on percentage of marketable fruits was observed significantly during storage of custard apple fruit at ambient temperature. The most of the marketable fruits were retained marketable till 4 to 8 days after storage without deteriorating their quality when fruits treated with different concentration of Chitosan, $\mathrm{CaCl}_{2}$, Benzyl adenine. Among all the treatments effect of coating on the marketable and spoilage fruit revealed that higher combinations $\left(\mathrm{T}_{12}-\mathrm{CaCl}_{2}\right.$ $-6.0 \%+$ BA- 150 ppm + Chitosan- $1.5 \%$ ) performed well on marketable fruit recorded maximum $(95.46 \%, 87.04 \%$ and $65.31 \%$ ). reducing loss of spoilage $(4.54 \%, 12.96 \%$, $34.69 \%$ ) on the days 4, 8, 12 of storage period respectively, over rest of treatments. 
Table.1 Effect of postharvest treatments on physical parameters of custard apple fruits

\begin{tabular}{|c|c|c|c|c|c|c|c|c|c|c|c|c|c|c|c|c|}
\hline \multirow[t]{2}{*}{$\begin{array}{c}\text { Symb } \\
\text { ol }\end{array}$} & \multirow[t]{2}{*}{ Treatment details } & \multirow[t]{2}{*}{$\begin{array}{l}\text { Initial } \\
\text { Value }\end{array}$} & \multicolumn{4}{|c|}{ Reduction in Fruit length (cm) } & \multirow{2}{*}{$\begin{array}{c}\text { Initia } \\
1 \\
\text { Value }\end{array}$} & \multicolumn{4}{|c|}{$\begin{array}{l}\text { Reduction in Fruit diameter } \\
(\mathbf{c m})\end{array}$} & \multirow{2}{*}{$\begin{array}{c}\text { Initia } \\
1 \\
\text { Value }\end{array}$} & \multicolumn{4}{|c|}{ Specific gravity } \\
\hline & & & $\begin{array}{c}0 \\
\text { days }\end{array}$ & 4 day & 8 day & $\begin{array}{c}12 \\
\text { day }\end{array}$ & & $\begin{array}{c}0 \\
\text { days }\end{array}$ & 4 day & 8 day & 12 day & & $\begin{array}{c}0 \\
\text { days }\end{array}$ & 4 day & 8 day & $\begin{array}{c}12 \\
\text { day }\end{array}$ \\
\hline To & Control & 5.33 & 0.00 & 0.25 & 0.35 & 0.55 & 5.77 & 0.00 & 0.26 & 0.37 & 0.58 & 1.23 & 0.00 & 0.07 & 0.06 & 0.05 \\
\hline $\mathbf{T}_{1}$ & $\mathrm{CaCl}_{2}(2.0 \%)$ & 5.83 & 0.00 & 0.23 & 0.33 & 0.54 & 6.21 & 0.00 & 0.23 & 0.33 & 0.55 & 1.25 & 0.00 & 0.08 & 0.04 & 0.04 \\
\hline $\mathbf{T}_{2}$ & $\mathrm{CaCl}_{2}(4.0 \%)$ & 5.54 & 0.00 & 0.17 & 0.28 & 0.47 & 5.90 & 0.00 & 0.19 & 0.30 & 0.51 & 1.25 & 0.00 & 0.06 & 0.06 & 0.04 \\
\hline $\mathbf{T}_{3}$ & $\mathrm{CaCl}_{2}(6.0 \%)$ & 5.13 & 0.00 & 0.16 & 0.26 & 0.46 & 5.73 & 0.00 & 0.18 & 0.29 & 0.50 & 1.23 & 0.00 & 0.05 & 0.05 & 0.04 \\
\hline $\mathbf{T}_{4}$ & $\begin{array}{l}\text { Benzyl adenine } \\
\quad(50 \text { ppm })\end{array}$ & 5.58 & 0.00 & 0.20 & 0.30 & 0.51 & 5.92 & 0.00 & 0.21 & 0.31 & 0.53 & 1.22 & 0.00 & 0.06 & 0.05 & 0.05 \\
\hline $\mathbf{T}_{5}$ & $\begin{array}{l}\text { Benzyl adenine } \\
\quad(100 \text { ppm) }\end{array}$ & 5.29 & 0.00 & 0.18 & 0.28 & 0.48 & 5.85 & 0.00 & 0.19 & 0.29 & 0.49 & 1.28 & 0.00 & 0.05 & 0.05 & 0.04 \\
\hline $\mathbf{T}_{6}$ & $\begin{array}{l}\text { Benzyl adenine } \\
\quad(150 \text { ppm) }\end{array}$ & 5.37 & 0.00 & 0.18 & 0.27 & 0.47 & 5.65 & 0.00 & 0.18 & 0.28 & 0.48 & 1.22 & 0.00 & 0.06 & 0.05 & 0.05 \\
\hline $\mathbf{T}_{7}$ & Chitosan (0.5 \%) & 5.38 & 0.00 & 0.19 & 0.29 & 0.50 & 5.66 & 0.00 & 0.21 & 0.32 & 0.51 & 1.21 & 0.00 & 0.05 & 0.05 & 0.04 \\
\hline $\mathbf{T}_{8}$ & Chitosan (1.0 \%) & 5.96 & 0.00 & 0.17 & 0.27 & 0.47 & 6.63 & 0.00 & 0.18 & 0.28 & 0.49 & 1.25 & 0.00 & 0.05 & 0.05 & 0.04 \\
\hline $\mathbf{T}_{9}$ & Chitosan (1.5 \%) & 5.53 & 0.00 & 0.16 & 0.26 & 0.46 & 6.00 & 0.00 & 0.17 & 0.27 & 0.47 & 1.26 & 0.00 & 0.04 & 0.04 & 0.03 \\
\hline $\mathbf{T}_{10}$ & $\begin{array}{c}\mathrm{CaCl}_{2}(2.0 \%) \\
+\mathrm{BA}(50 \mathrm{PPM}) \\
+ \text { Chitosan }(0.5 \%)\end{array}$ & 5.56 & 0.00 & 0.17 & 0.27 & 0.47 & 6.01 & 0.00 & 0.21 & 0.30 & 0.50 & 1.24 & 0.00 & 0.04 & 0.03 & 0.03 \\
\hline $\mathbf{T}_{11}$ & $\begin{array}{c}\mathrm{CaCl}_{2}(4.0 \%) \\
+\mathrm{BA}(100 \mathrm{PPM}) \\
+ \text { Chitosan }(1.0 \%)\end{array}$ & 5.53 & 0.00 & 0.15 & 0.24 & 0.43 & 5.93 & 0.00 & 0.16 & 0.27 & 0.46 & 1.26 & 0.00 & 0.04 & 0.04 & 0.03 \\
\hline $\mathbf{T}_{12}$ & $\begin{array}{c}\mathrm{CaCl}_{2}(6.0 \%) \\
+\mathrm{BA}(150 \mathrm{PPM}) \\
+ \text { Chitosan }(1.5 \%)\end{array}$ & 5.53 & 0.00 & 0.14 & 0.22 & 0.42 & 5.98 & 0.00 & 0.15 & 0.26 & 0.45 & 1.24 & 0.00 & 0.03 & 0.03 & 0.02 \\
\hline & SEm \pm & & 0.00 & 0.01 & 0.01 & 0.01 & & 0.00 & 0.00 & 0.00 & 0.00 & & 0.00 & 0.01 & 0.01 & 0.00 \\
\hline & $\mathrm{CD}$ at $5 \%$ & & 0.00 & 0.03 & 0.03 & 0.03 & & 0.00 & 0.01 & 0.01 & 0.01 & & NS & NS & NS & NS \\
\hline
\end{tabular}


Table.2 Effect of postharvest treatments on Marketable (\%) and Spoilage (\%) of custard apple fruits

\begin{tabular}{|c|c|c|c|c|c|c|c|c|c|c|c|}
\hline \multirow{2}{*}{$\begin{array}{l}\text { Symb } \\
\text { ol }\end{array}$} & \multirow[t]{2}{*}{ Treatment details } & \multirow{2}{*}{$\begin{array}{l}\text { Initial } \\
\text { Value }\end{array}$} & \multicolumn{4}{|c|}{ Marketable fruit $(\%)$} & \multirow{2}{*}{$\begin{array}{c}\text { Initia } \\
1 \\
\text { Value }\end{array}$} & \multicolumn{4}{|c|}{ Spoilage fruit (\%) } \\
\hline & & & O days & 4 day & 8 day & 12 day & & 0 days & 4 day & 8 day & 12 day \\
\hline To & Control & 100.00 & 100.00 & 91.47 & 39.54 & 29.31 & 0.00 & 0.00 & 8.53 & 60.46 & 70.69 \\
\hline $\mathbf{T}_{1}$ & $\mathrm{CaCl}_{2}(2.0 \%)$ & 100.00 & 100.00 & 92.12 & 63.52 & 48.03 & 0.00 & 0.00 & 7.88 & 36.48 & 51.97 \\
\hline $\mathbf{T}_{2}$ & $\mathrm{CaCl}_{2}(4.0 \%)$ & 100.00 & 100.00 & 92.26 & 73.55 & 52.61 & 0.00 & 0.00 & 7.74 & 26.45 & 47.39 \\
\hline $\mathbf{T}_{\mathbf{3}}$ & $\mathrm{CaCl}_{2}(6.0 \%)$ & 100.00 & 100.00 & 93.14 & 80.12 & 60.06 & 0.00 & 0.00 & 6.86 & 19.88 & 39.94 \\
\hline $\mathbf{T}_{4}$ & $\begin{array}{c}\text { Benzyl adenine (50 } \\
\text { ppm) }\end{array}$ & 100.00 & 100.00 & 92.31 & 75.23 & 54.70 & 0.00 & 0.00 & 7.69 & 24.77 & 45.30 \\
\hline $\mathbf{T}_{5}$ & $\begin{array}{c}\text { Benzyl adenine (100 } \\
\text { ppm) }\end{array}$ & 100.00 & 100.00 & 92.99 & 80.04 & 59.55 & 0.00 & 0.00 & 7.01 & 19.96 & 40.45 \\
\hline $\mathbf{T}_{6}$ & $\begin{array}{c}\text { Benzyl adenine (150 } \\
\text { ppm) }\end{array}$ & 100.00 & 100.00 & 94.43 & 82.53 & 62.01 & 0.00 & 0.00 & 5.57 & 17.47 & 37.99 \\
\hline $\mathbf{T}_{7}$ & Chitosan (0.5 \%) & 100.00 & 100.00 & 92.43 & 79.41 & 57.90 & 0.00 & 0.00 & 7.57 & 20.59 & 42.10 \\
\hline $\mathbf{T}_{8}$ & Chitosan (1.0 \%) & 100.00 & 100.00 & 93.16 & 80.57 & 60.84 & 0.00 & 0.00 & 6.84 & 19.43 & 39.16 \\
\hline $\mathbf{T}_{9}$ & Chitosan (1.5 \%) & 100.00 & 100.00 & 94.75 & 84.61 & 62.48 & 0.00 & 0.00 & 5.25 & 15.39 & 37.52 \\
\hline $\mathbf{T}_{10}$ & $\begin{array}{c}\mathrm{CaCl}_{2}(2.0 \%)+\mathrm{BA} \\
(50 \mathrm{PPM})+\text { Chitosan } \\
(0.5 \%)\end{array}$ & 100.00 & 100.00 & 92.77 & 79.65 & 59.22 & 0.00 & 0.00 & 7.23 & 20.35 & 40.78 \\
\hline $\mathbf{T}_{11}$ & $\begin{array}{c}\mathrm{CaCl}_{2}(4.0 \%)+\mathrm{BA} \\
(100 \mathrm{PPM}) \\
+ \text { Chitosan }(1.0 \%)\end{array}$ & 100.00 & 100.00 & 95.11 & 85.30 & 64.90 & 0.00 & 0.00 & 4.89 & 14.70 & 35.10 \\
\hline \multirow[t]{3}{*}{$\mathbf{T}_{12}$} & $\begin{array}{c}\mathrm{CaCl}_{2}(6.0 \%)+\mathrm{BA} \\
(150 \text { PPM }) \\
+ \text { Chitosan }(1.5 \%)\end{array}$ & 100.00 & 100.00 & 95.46 & 87.04 & 65.31 & 0.00 & 0.00 & 4.54 & 12.96 & 34.69 \\
\hline & SEm \pm & & 0.00 & 0.14 & 0.92 & 0.52 & & 0.00 & 0.14 & 0.92 & 0.52 \\
\hline & CD at $5 \%$ & & 0.00 & 0.40 & 2.66 & 1.52 & & 0.00 & 0.40 & 2.66 & 1.50 \\
\hline
\end{tabular}


Table.3 Effect of postharvest treatments on Biochemical parameters of custard apple fruits

\begin{tabular}{|c|c|c|c|c|c|c|c|c|c|c|c|c|c|c|c|c|}
\hline \multirow{2}{*}{$\begin{array}{c}\text { Symb } \\
\text { ol }\end{array}$} & \multirow[t]{2}{*}{ Treatment details } & \multirow{2}{*}{$\begin{array}{l}\text { Initia } \\
1 \\
\text { Value }\end{array}$} & \multicolumn{4}{|c|}{ TSS $\left({ }^{0} \mathbf{B}\right)$} & \multirow{2}{*}{$\begin{array}{l}\text { Initia } \\
1 \\
\text { Value }\end{array}$} & \multicolumn{4}{|c|}{ Acidity \% } & \multirow{2}{*}{$\begin{array}{c}\text { Initia } \\
1 \\
\text { Value }\end{array}$} & \multicolumn{4}{|c|}{ Ascorbic Acid (mg/100mg) } \\
\hline & & & $\begin{array}{c}0 \\
\text { days }\end{array}$ & 4 day & 8 day & $\begin{array}{c}12 \\
\text { day }\end{array}$ & & $\begin{array}{c}0 \\
\text { days }\end{array}$ & 4 day & 8 day & 12 day & & $\begin{array}{c}0 \\
\text { days }\end{array}$ & 4 day & 8 day & $\begin{array}{c}12 \\
\text { day }\end{array}$ \\
\hline To & Control & 18.56 & 0.00 & 0.75 & 4.36 & 0.07 & 0.00 & 6.55 & 7.06 & 5.60 & 0.00 & 23.26 & 0.00 & 5.39 & 3.87 & 1.64 \\
\hline $\mathbf{T}_{1}$ & $\mathrm{CaCl}_{2}(2.0 \%)$ & 19.54 & 0.00 & 0.94 & 4.52 & 0.18 & 0.00 & 6.55 & 7.06 & 5.60 & 0.00 & 24.03 & 0.00 & 5.86 & 4.95 & 1.98 \\
\hline $\mathbf{T}_{2}$ & $\mathrm{CaCl}_{2}(4.0 \%)$ & 19.64 & 0.00 & 1.07 & 5.23 & 0.96 & 0.00 & 6.55 & 7.06 & 5.60 & 0.00 & 25.97 & 0.00 & 6.25 & 5.42 & 2.35 \\
\hline $\mathbf{T}_{3}$ & $\mathrm{CaCl}_{2}(6.0 \%)$ & 20.03 & 0.00 & 2.08 & 5.42 & 1.12 & 0.00 & 6.55 & 7.06 & 5.60 & 0.00 & 26.15 & 0.00 & 6.78 & 5.75 & 2.59 \\
\hline $\mathbf{T}_{4}$ & $\begin{array}{l}\text { Benzyl adenine } \\
\quad(50 \mathrm{ppm})\end{array}$ & 19.55 & 0.00 & 0.97 & 4.90 & 0.66 & 0.00 & 6.55 & 7.06 & 5.60 & 0.00 & 24.30 & 0.00 & 6.07 & 5.12 & 2.00 \\
\hline $\mathbf{T}_{5}$ & $\begin{array}{l}\text { Benzyl adenine } \\
\text { (100 ppm) }\end{array}$ & 20.11 & 0.00 & 1.60 & 5.26 & 1.07 & 0.00 & 6.55 & 7.06 & 5.60 & 0.00 & 25.98 & 0.00 & 6.42 & 5.64 & 2.48 \\
\hline $\mathbf{T}_{6}$ & $\begin{array}{l}\text { Benzyl adenine } \\
\text { (150 ppm) }\end{array}$ & 20.68 & 0.00 & 2.30 & 5.44 & 1.32 & 0.00 & 6.55 & 7.06 & 5.60 & 0.00 & 26.14 & 0.00 & 6.82 & 5.95 & 2.62 \\
\hline $\mathbf{T}_{7}$ & Chitosan (0.5 \%) & 19.73 & 0.00 & 0.99 & 4.96 & 0.92 & 0.00 & 6.55 & 7.06 & 5.60 & 0.00 & 24.78 & 0.00 & 6.14 & 5.38 & 2.08 \\
\hline $\mathbf{T}_{8}$ & Chitosan (1.0 \%) & 20.86 & 0.00 & 1.78 & 5.39 & 1.11 & 0.00 & 6.55 & 7.06 & 5.60 & 0.00 & 26.52 & 0.00 & 6.65 & 5.69 & 2.54 \\
\hline $\mathbf{T}_{9}$ & Chitosan (1.5 \%) & 20.98 & 0.00 & 2.92 & 5.53 & 1.40 & 0.00 & 6.55 & 7.06 & 5.60 & 0.00 & 27.02 & 0.00 & 6.83 & 6.05 & 2.62 \\
\hline $\mathbf{T}_{10}$ & $\begin{array}{c}\mathrm{CaCl}_{2}(2.0 \%) \\
+\mathrm{BA}(50 \mathrm{PPM}) \\
+ \text { Chitosan }(0.5 \%)\end{array}$ & 21.02 & 0.00 & 2.99 & 5.55 & 1.38 & 0.00 & 6.55 & 7.06 & 5.60 & 0.00 & 26.15 & 0.00 & 6.14 & 6.10 & 2.09 \\
\hline $\mathbf{T}_{11}$ & $\begin{array}{c}\mathrm{CaCl}_{2}(4.0 \%) \\
+\mathrm{BA}(100 \mathrm{PPM}) \\
+ \text { Chitosan }(1.0 \%)\end{array}$ & 21.21 & 0.00 & 3.05 & 5.60 & 1.42 & 0.00 & 6.55 & 7.06 & 5.60 & 0.00 & 28.20 & 0.00 & 6.86 & 6.08 & 2.93 \\
\hline $\mathbf{T}_{12}$ & $\begin{array}{c}\mathrm{CaCl}_{2}(6.0 \%) \\
+\mathrm{BA}(150 \text { PPM }) \\
+ \text { Chitosan }(1.5 \%)\end{array}$ & 21.73 & 0.00 & 3.07 & 5.67 & 1.50 & 0.00 & 6.55 & 7.06 & 5.60 & 0.00 & 29.55 & 0.00 & 7.33 & 6.10 & 2.94 \\
\hline & SEm \pm & & 0.00 & 0.32 & 0.14 & 0.16 & 0.00 & 6.55 & 7.06 & 5.60 & 0.00 & & 0.00 & 0.19 & 0.15 & 0.14 \\
\hline & $\mathrm{CD}$ at $5 \%$ & & 0.00 & 0.94 & 0.41 & 0.47 & 0.00 & 6.55 & 7.06 & 5.60 & 0.00 & & 0.00 & 0.55 & 0.44 & 0.41 \\
\hline
\end{tabular}


Although, it was significantly at par with $\mathrm{T}_{11}$ in case of marketable fruits $(95.11 \%, 85.30 \%$ and $64.90 \%)$ and Spoilage fruits (4.89\%, $14.70 \%$ and $35.10 \%$ ) on the days $4,8,12$ of storage period, respectively. While, minimum marketable fruit recorded $(91.47 \%, 39.54 \%$ and $29.31 \%$ ) and maximum spoilage fruit $(8.53 \%, 60.46$ and $70.69 \%)$ were noticed at 4 , 8,12 days of storage period respectively over all the treatments (Table 2).

Increase the marketable quality and shelf life of the fruit due to the inhibit ethylene synthesis and reduce the respiration rate by the combined effect of chitosan, benzyl adenine and calcium chloride. Chitosan provided the lowest rotted aonla fruits might be due to inhibition of sporulation and spore germination of rot causing fungus by wax coating treatment (Jakhar and Singh, 2008). As for the combination of chitosan and calcium chloride, its potential as fungal decay inhibitors has been reported also by Munoz et al., (2008). Similarly result showed by ElBadawy,(2012) on peach. Results of this study are in agreement with previous reports by Jayachandran et al., (2007) in Guava, Chauhan, (2014) in mango, Reddy, (2007) in papaya and Elham et al., (2007) in apricot.

\section{Biochemical parameters}

The biochemical parameters significantly influenced by the application of individual and combination of coatings on fruits during investigation. The effect of $\mathrm{CaCl}_{2}, \mathrm{BA}$ and Chitosan coating on rate of changes of biochemical parameters on the day of $0,4,8$ and 12 days of storage period respectively (Table-3). The higher combinations $\left(\mathrm{T}_{12}-\right.$ $\mathrm{CaCl}_{2}-6.0 \%+\mathrm{BA}-150$ ppm + Chitosan$1.5 \%$ ) recorded maximum total soluble solids $\left(0.00{ }^{0} \mathrm{~B}, 3.07{ }^{0} \mathrm{~B}, 5.67{ }^{0} \mathrm{~B}\right.$ and $\left.1.50{ }^{0} \mathrm{~B}\right)$ on 0 , 4,8 and 12 days of storage period, respectively. Minimum acidity $(0.00 \%$, $42.25 \%, 45.59 \%$ and $46.37 \%$ ) and maximum ascorbic acid $\quad(0.00 \quad \mathrm{mg} / 100 \mathrm{gm}, \quad 7.33$ $\mathrm{mg} / 100 \mathrm{gm}, \quad 6.10 \mathrm{mg} / 100 \mathrm{gm}$ and 2.94 $\mathrm{mg} / 100 \mathrm{gm}$ ) were observed with the application of higher combination of treatments $\mathrm{T}_{12}$ over all the treatment combinations at 4,8 and 12 days of storage duration respectively. While lowest total soluble solids $\left(0.00{ }^{0} \mathrm{~B}, 0.75{ }^{0} \mathrm{~B}, 4.36{ }^{0} \mathrm{~B}\right.$ and $\left.0.07{ }^{0} \mathrm{~B}\right)$, ascorbic acid (0.00 mg/100gm, 5.39 $\mathrm{mg} / 100 \mathrm{gm}, \quad 3.87 \mathrm{mg} / 100 \mathrm{gm}$ and 1.64 $\mathrm{mg} / 100 \mathrm{gm}$ ) were recorded on $0,4,8$ and 12 days of storage period of duration, respectively. The maximum acidity \% (10.03 $\%, 20.03 \%$ and $22.70 \%$ ) was found with treatment $\mathrm{T}_{0}$ at $4,8,12$ days of storage period, respectively (Table 3 ).

The combined effect of chitosan, calcium chloride and benzyl adenine maintain the quality and biochemical parameters due to the changes brought about in total soluble solids of fruits during ripening are mainly due to degradation of starch and accumulation of sugar. Chitosan and calcium chloride coating with combinations improve the quality and shelf life of mango (Chauhan, et al., 2014). These results are in accordance with the findings of Jholgiker and Reddy (2007) in custard apple and Reddy et al., (2014) in guava.

\section{References}

Abdel, A. N. G.; Abdel Gayed, N.; Shaarawi, S. A. T. M. A.; Elkhishen, M. A. and Elsherbini, N. R. M. (2017). Preharvest application of calcium chloride and chitosan on fruit quality and storability of 'Early Swelling' peach during cold storage. Ciênc. Agrotec, 41(2): 220-231.

Bhardwaj, R. L.; Sen, N. L. and Mukherjee, S. (2005). Effect of benzyl adenine on physic- chemical characterstics and shelf-life of mandarin cv. Nagpur santra. Indian J. Hort. 62: 181-183. 
Chauhan, S.; Gupta, K. C. and Agrawal, M. (2014). Efficacy of Chitosan and Calcium chloride on Post harvest storage period of Mango with the application of hurdle technology Int.J.Curr.Microbiol.App.Sci. 3(5): 731-740.

Elham Z. Abd El-Motty, Mohamed H. ElShiekh, Mohamed F.M. and Shahin, M. I. F. Fawzy (2007). Effect of Preharvest Calcium and Boric Acid Treatments on Characteristics and Storability of "Canino" Apricot Fruits. J. Agric. Biolo. Sci., 3(5): 430-439.

El-Badawy, H. E. M.(2012). Effect of Chitosan and Calcium Chloride Spraying on Fruits Quality of Florida Prince Peach Under Cold Storage. Res. J. Agric. \& Biol. Sci. 8(2): 272-281.

Jayachandran, K. S.; Srihari, D. and Reddy, Y.N. (2007). Post-harvest application of selected antioxidants to improve the shelf life of guava fruit. Acta Hortic. 735: 627-632.

Jakhar, R. P. and Singh, D. (2008). Postharvest effects of packaging materials, neem leaf extract and fumigation on colour, shrivelling and rotting of aonla (Emblica officinalis). Indian J. Arid Hort. 3 (1):27-32.

Jholgiker, P. and Reddy, B. S. (2007). Effect of different surface coating material on post-harvest physiology of Annona squamosa L. fruits under ambient and zero energy cool chamber storage. Indian J. Hort. 64(1): 41-44.

Lal, S.; Kumar, D.; Singh, D. B.; Ahmed, N. ; Kumar, R. and Dar, G. A. (2011). Effect of pre-harvest application of calcium chloride and gibberellic acid on shelf-life and post-harvest quality of apricot (Prunus armeniaca L.) cv. Harcot. J.Hortl. Sci. 6(1):46-51.

Li, H. and Yu, T. (2001). Effect of chitosan on incidence of brown rot, quality and physiological attributes of post harvest peach fruit. J. Sci. Food. Agri. 81: 269274.

Mahadevbhai, C. C. and Patel A. P. (2018). Effect of grading and post-harvest application of chemicals and biochemical parameters of custard apple (Annona squamosal L.) cv. Balanagar. Int. J. Curr. Microbiol. App. Sci. 7(11): 1085-1093.

Medlicott, A. P.; Sigrist, J. M.; Reynolds, S. B. and Thompson, A. K. (1987). Effect of ethylene and acetylene on mango fruit ripening. Ann. Appl. Biol. 111:439-444.

Munoz, P. H; Almenar, E.; Valle, V. D. and Veley, D. D. (2008). Effect of chitosan coating combined with postharvest calcium treatment on strawberry (Fragara ananassa) quality during refrigerated storage. Food Chemistry. 110(2):428-435.

Patel, N.; Naik, A. G. and Arbat, S. S. (2011). Response of postharvest chemical treatments on shelf life and quality of custard apple $\mathrm{cv}$. balanagar. Indian $J$. Hort. 68(4): 547- 550.

Ranganna, S. (1996). Handbook of analysis and quality control for fruits and vegetable products. New Delhi. Tata McGraw-Hill Publishing. 40-42.

Reddy, R. Y. 2007. Effect of gamma irradiation and antioxidants on post harvest shelf life of papaya (Carica papaya) 'Red lady', M.Sc. thesis, Acharya N. G. Ranga Agr. Univ., Hyderabad, India

Reddy, T. S.; Babuand, J. D. and Polaiah, A. C. (2014). Effect of antioxidants on shelf life of guava (psidium guajava L.) Cv. Allahabad safeda. Plant Archives. 14(1): 575-578.

Sihag, R. P.; Behiwal, L. S. and Mehta, P. K. (2005). Effect of postharvest application of potassium permanganate on shelf life of Peach fruit. Haryana. $J$. Hort. Sci. 34 (3-4): 259-260. 
Shiekh, R. A.; Malik, M. A.; Al-Thabaiti, S. A. and Shiekh, M. A. (2013). Chitosan as a Novel Edible Coating for Fresh Fruits. Food Sci. Technol. Res., 19 (2): $139-155$.

Thokchom, R. and Mandal, G. (2018). Effect of postharvest treatments on physical characteristics of mango. $J$. Pharmacogn. Phytochem. 8(1): 22392243.

Trung, T. S.; Phuong, N. T. H. and Stevens,
W. H. (2011). Protective effect of chitosan coating and polyethylene film wrapping on postharvest storage of sugar-apples. Asian. J. Food Ag- Ind. 4(2): 81-90.

Wills, R. B. H.; Warton, M. A.; Mussa, D. M. D. N. and Chew, L. P. (2001). Ripening of climacteric fruits initiated at low ethylene levels. Austral. J. Expt. Agr. 41 (1): 89-92.

\section{How to cite this article:}

Megha Patidar, Jyoti Kanwar, O. P. Singh and Rathore, G. P. S. 2021. Response of Post Harvest Treatments on Shelf Life of Custard Apple (Annona squamosa L.) variety Arka Sahan during Storage. Int.J.Curr.Microbiol.App.Sci. 10(04): 400-408.

doi: https://doi.org/10.20546/ijcmas.2021.1004.043 